\title{
PERBANDINGAN STRATEGI PEMBELAJARAN PENINGKATAN KEMAMPUAN BERPIKIR DAN PEMBERDAYAAN BERPIKIR MELALUI PERTANYAAN TERHADAP HASIL BELAJAR MAHASISWA
}

\author{
Loviana Rekha ${ }^{1)}$ Arlian Firda ${ }^{2)}$ Rikizaputra $^{3)}$ Rahmat Ramadansur \\ ${ }^{122) 3) 4)}$ Pendidikan Biologi FKIP Universitas Lancang Kuning \\ email ${ }^{1)}$ :loviana.rekha@gmail.com,email ${ }^{2}$ : rikizaputra@unilak.ac.id \\ email $^{3)}$ :arlian_arai@unilak.ac.id,email ${ }^{4)}$ :rahmatramadansur89@unilak.ac.id
}

\begin{abstract}
ABSTRAK: Mata kuliah bioteknologi khususnya pada materi kultur jaringan tumbuhan merupakan materi yang komplek sehingga mahasiswa kesusahan untuk memahami materi tersebut, sehingga mereka menjadi bosan, pasif dan malas untuk berpikir aktif dalam belajar. Penelitian ini bertujuan untuk mengetahui Perbandingan Hasil Belajar Mahasiswa Pada Kelas Strategi Pembelajaran Peningkatan Kemampuan Berpikir (SPPKB) dan Pemberdayaan Berpikir Melalui Pertanyaan (PBMP). Penelitian ini dilaksanakan pada mahasiswa reguler semester VI Pendidikan Biologi Universitas Lancang Kuning Pekanbaru bulan Mei 2019. Metode penelitian yang digunakan adalah quasi eksperimental dengan desain pretest-posttest non-equivalent group design. Sampel penelitian adalah mahasiswa semester $\mathrm{VI}_{1}$ dan $\mathrm{VI}_{2}$ dengan teknik pengambilan total sampling. Pengumpulan data dilakukan melalui pretest, posttest, dan lembar observasi. Teknik analisis data dalam penelitian ini berupa uji N-Gain, Normalitas, Homogenitas dan uji-t. Rerata $N$-Gain pada kelas SPPKB 0.28 (kategori rendah), sedangkan kelas PBMP 0.46 (kategori sedang). Hasil uji-t terdapat perbedaan yang signifikan antara kelas PBMP dan kelas SPPKB. Berdasarkan hasil penelitian dapat disimpulkan bahwa terdapat perbandingan Hasil Belajar Mahasiswa Pada Kelas Strategi Pembelajaran Peningkatan Kemampuan Berpikir (SPPKB) dan Pemberdayaan Berpikir Melalui Pertanyaan (PBMP).
\end{abstract}

\section{Kata Kunci: Strategi Pembelajaran Peningkatan Kemampuan Berpikir (SPPKB), Pemberdayaan Berpikir Melalui Pertanyaan (PBMP), Hasil belajar}

\begin{abstract}
Biotechnology courses especially in plant tissue culture material are complex materials so that students have difficulty understanding the material, so they become bored, passive and lazy to think actively in learning. This study aims to compare the Student Learning Outcomes in the classroom Learning Strategies for Enhancing Thinking Ability (ETA) and Empowerment Thinking Through Questions (ETTQ). This research was conducted in the 6th semester regular students of Biology Education at Lancang Kuning Pekanbaru University in May 2019. The research method used was quasi-experimental with a pretestposttest non-equivalent group design. The study sample was semester $V I_{1}$ and $V I_{2}$ students with a total sampling technique. Data collection was done through pretest, posttest, and observation sheet. Data analysis techniques in this study were $N$-gain, Normality, Homogeneity and t-test. That mean $N$-Gain in the ETA class is 0.28 (low category), while the ETTQ class is 0.46 (medium category). The results of the t-test have significant differences between the ETTQ class and the
\end{abstract}


ETA class. Based on the results of the study, it can be concluded that there are differences in student Learning Outcomes in the Classroom Learning Strategies for Enhancing Thinking Ability (ETA) and Empowerment Thinking Through Questions (ETTQ) Against Student Learning in Biotechnology Courses.

\section{Keywords: Learning Strategies Enhancing Thinking Ability (ETA), Empowerment Thinking Through Questions (ETTQ), Learning Outcomes}

\section{PENDAHULUAN}

Pendidikan merupakan hal yang penting dalam membangun peradaban bangsa. Pendidikan adalah satu-satunya aset untuk membangun sumber daya manusia yang berkualitas. Menurut undang-undang No. 20 tahun 2003 tentang Sistem Pendidikan Nasional menyatakan bahwa pendidikan adalah usaha sadar dan terencana untuk mewujudkan suasana belajar dan proses pembelajaran agar siswa secara aktif mengembangkan potensi dirinya sehingga memiliki kekuatan spiritual keagamaan, pengendalian diri, kepribadian, kecerdasan, akhlak mulia, serta keterampilan yang diperlukan oleh dirinya, masyarakat, bangsa, dan negara (Suwarno, 2009).

Salah satu masalah yang dihadapi dunia pendidikan kita adalah lemahnya proses pembelajaran (Sanjaya, 2009). Dalam proses pembelajaran, peserta didik kurang didorong untuk mengembangkan kemampuan berfikir. Proses pembelajaran di dalam kelas diarahkan kepada kemampuan peserta didik untuk menghafal informasi, otak peserta didik dipaksa untuk mengingat dan menimbun berbagai informasi tanpa dituntut untuk memahami informasi yang diingatnya itu menghubungkan dengan kehidupan seharihari. Akibatnya, ketika peserta didik lulus dari sekolah, mereka pintar secara teoritis, akan tetapi mereka miskin aplikasi.

Secara umum hasil belajar adalah kemampuan yang diperoleh peserta didik setelah melalui kegiatan belajar. Menurutnya juga peserta didik yang berhasil dalam belajar ialah berhasil mencapai tujuan-tujuan pembelajaran atau tujuan instruksional (Abdurrahman, 1999).

Strategi pembelajaran peningkatan kemampuan berpikir adalah pembelajaran yang tertumpu kepada pengembangan kemampuan berpikir peserta didik melalui telaahan fakta-fakta atau pengalaman anak sebagai bahan untuk memecahkan masalah yang diajukan (Sanjaya, 2009). Sedangkan menurut Anwar (2010) strategi pembelajaran peningkatan kemampuan 
berfikir adalah strategi meningkatkan berfikir peserta didik, sehingga agar mereka dapat berfikir mencari dan menemukan materi pelajaran sendiri.

Berdasarkan wawancara dan observasi yang telah dilakukan dengan Bapak Arlian Firda, M.Si selaku dosen pengampu mata kuliah bioteknologi diketahui terdapat beberapa permasalahan dalam pembelajaran kultur jaringan tumbuhan pada mata kuliah bioteknologi. Permasalahan tersebut diantaranya adalah kurang

tersedianya fasilitas yang memadai untuk pembelajaran kultur jaringan tumbuhan. Materi kultur jaringan tumbuhan membutuhkan alat dan bahan yang tersedia di laboratorium, tetapi laboratorium yang terdapat di pendidikan biologi tidak menunjang untuk kegiatan praktikum tersebut. Materi kultur jaringan ini juga merupakan materi yang komplek sehingga mahasiswa pendidikan biologi merasa kesusahan untuk bisa memahami materi tersebut. Permasalahan lain yang muncul ketika mahasiswa pendidikan biologi menemui kesulitan untuk mempelajari materi kultur jaringan tumbuhan akan membuat mereka bosan, dan pasif dalam pembelajaran, hal ini membuat mereka malas untuk berfikir aktif dalam pembelajaran. Akibatnya dari permasalahan tersebut mahasiswa pendidikan biologi mendapatkan nilai yang rendah pada materi kultur jaringan tumbuhan, nilai yang diperoleh rata-rata hanya mencapai skor 55.

Untuk mengatasi permasalahan tersebut, maka perlu perbaikan terkait strategi pembelajaran yang diharapkan mampu meningkatkan hasil belajar mahasiswa pendidikan biologi Universitas Lancang Kuning T.A 2018/2019. Adapun strategi pembelajaran yang digunakan adalah Strategi Pembelajaran Peningkatan Kemampuan Berpikir (SPPKB) dan Pemberdayaan Berpikir Melalui Pertanyaan (PBMP). SPPKB dan PBMP merupakan strategi yang memiliki tujuan yang sama yaitu mendorong mahasiswa untuk mampu meningkatkan kemampuan berfikir.

Strategi Pembelajaran Peningkatan Kemampuan Berpikir (SPPKB) merupakan suatu strategi pembelajaran yang bertumpu pada proses peningkatan kemampuan berpikir siswa melalui proses telaah faktafakta, dan menghubungkan antara pengalaman yang dialami siswa dan dikaitkan dengan kehidupan nyata (Anisa et.al 2013), sedangkan Pemberdayaan Berpikir Melalui Pertanyaan (PBMP) merupakan pola pembelajaran yang dilaksanakan dengan tidak ada proses pembelajaran yang berlangsung secara informatif dan seluruhnya dilakukan 
melalui rangkaian atau jalinan pertanyaan yang telah dirancang secara tertulis dalam

\section{METODE PENELITIAN}

Penelitian ini merupakan Quasi eksperimental dengan desain pretestposttest non-equivalent group design (pretest-posttest yang tidak ekuivalen). Dalam penelitian ini kelompok perlakuan tidak dipilih secara random, sebelum diberikan perlakuan kedua kelompok diberi pretest untuk mengetahui kemampuan awal (Sugiyono, 2008).

Populasi dalam penelitian ini adalah mahasiswa reguler semester VI Pendidikan Biologi Universitas Lancang Kuning yang terdiri dari dua kelas paralel $\mathrm{VI}_{1}$ dan $\mathrm{VI}_{2}$ lembar-lembar PBMP (Corebima, 2009).

dengan jumlah 58 mahasiswa. Teknik pengambilan sampel pada penelitian ini adalah total sampling, karena menurut Sugiyono (2007) jumlah populasi yang kurang dari 100 maka semua populasi dijadikan sampel penelitian. Sampel yang diambil dari penelitian ini adalah 58 mahasiswa. $\mathrm{VI}_{1}$ menggunakan strategi SPKB dan $\mathrm{VI}_{2}$ menggunakan PBMP, persebaran pembagian kelas tidak berdasarkan tingkat kecerdasan mahasiswa.

\section{HASIL DAN PEMBAHASAN}

Berdasarkan penelitian yang telah dilakukan pada mata kuliah Bioteknologi Pendidikan Biologi di Fakultas Keguruan

dan Ilmu Pendidikan Universitas Lancang Kuning baik pada kelas SPPKB maupun kelas PBMP adalah sebagai berikut :

Tabel 1: Rekapitulasi Data N-Gain pada Kelas SPPKB dan Kelas PBMP

\begin{tabular}{|c|c|c|c|c|c|c|c|}
\hline \multirow[b]{2}{*}{ Nilai } & \multirow[b]{2}{*}{ Kelas } & \multirow[b]{2}{*}{$\mathrm{n}$} & \multicolumn{3}{|c|}{ Hasil Belajar } & \multirow[b]{2}{*}{ Rerata } & \multirow[b]{2}{*}{ Kategori } \\
\hline & & & $\begin{array}{l}\text { Nilai } \\
\text { Ideal }\end{array}$ & $\begin{array}{l}\text { Skor } \\
\text { Min }\end{array}$ & $\begin{array}{l}\text { Skor } \\
\text { Max }\end{array}$ & & \\
\hline Pretest & SPPKB & 28 & 1.00 & 0.06 & 0.73 & 0.28 & Rendah \\
\hline Posttest & PBMP & 35 & 1.00 & 0.18 & 0.81 & 0.46 & Sedang \\
\hline
\end{tabular}

Pada Tabel 1 nilai N-Gain minimum kelas SPPKB sebesar 0.06 sedangkan kelas PBMP sebesar 0.18. Hasil maksimum kelas SPPKB sebesar 0.73 sedangkan kelas PBMP 0.81. Rerata N-Gain kelas SPPKB adalah 0.28 dan pada kelas PBMP adalah 
0.46. Skala atau nilai ideal untuk N-Gain adalah 1.00 .
Perbandingan data rerata N-Gain pada kelas SPPKB dan kelas PBMP dapat dilihat pada diagram batang berikut :

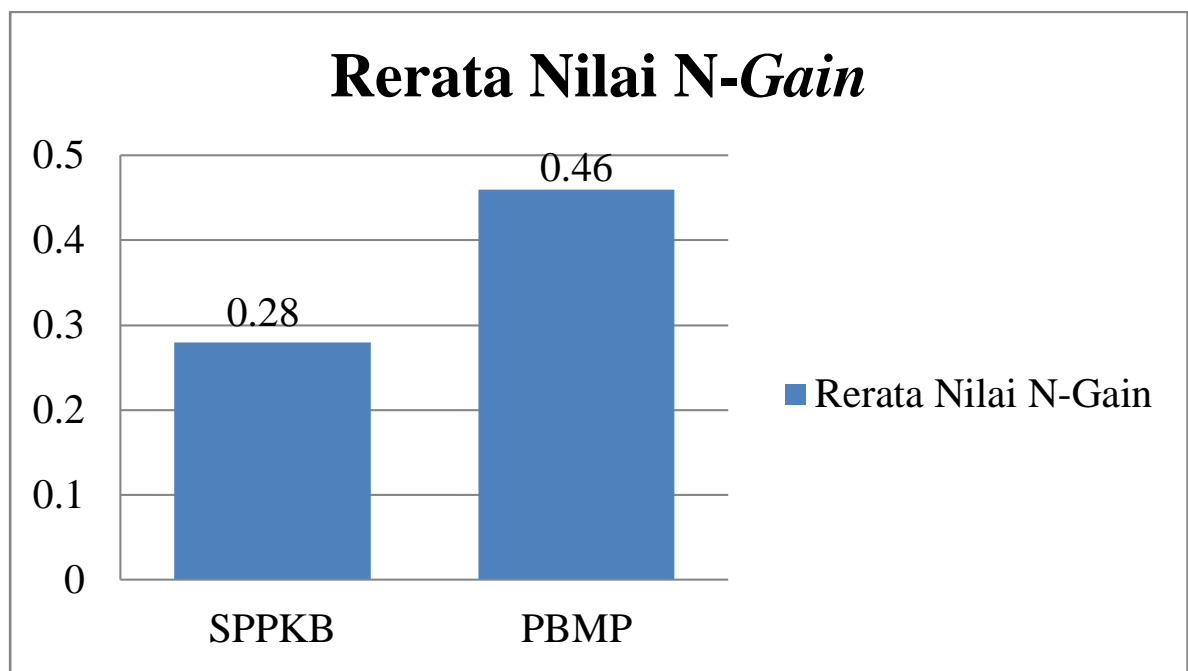

Gambar 4 : Diagram Batang Perbandingan N-Gain pada Kelas SPPKB dan Kelas PBM

Berdasarkan diagram batang pada gambar 4 dapat dilihat rerata N-Gain kelas SPPKB sebesar 0.28 (kategori rendah) dan rerata N-Gain kelas PBMP sebesar 0.46 (kategori sedang). Maka dapat dikatakan
$\mathrm{N}$-Gain kelas SPPKB lebih rendah dari pada kelas PBMP

Berikut ini merupakan perbandingan data N-Gain per siswa pada kelas SPPKB dan kelas PBMP yang digambar dengan diagram garis berikut ini :

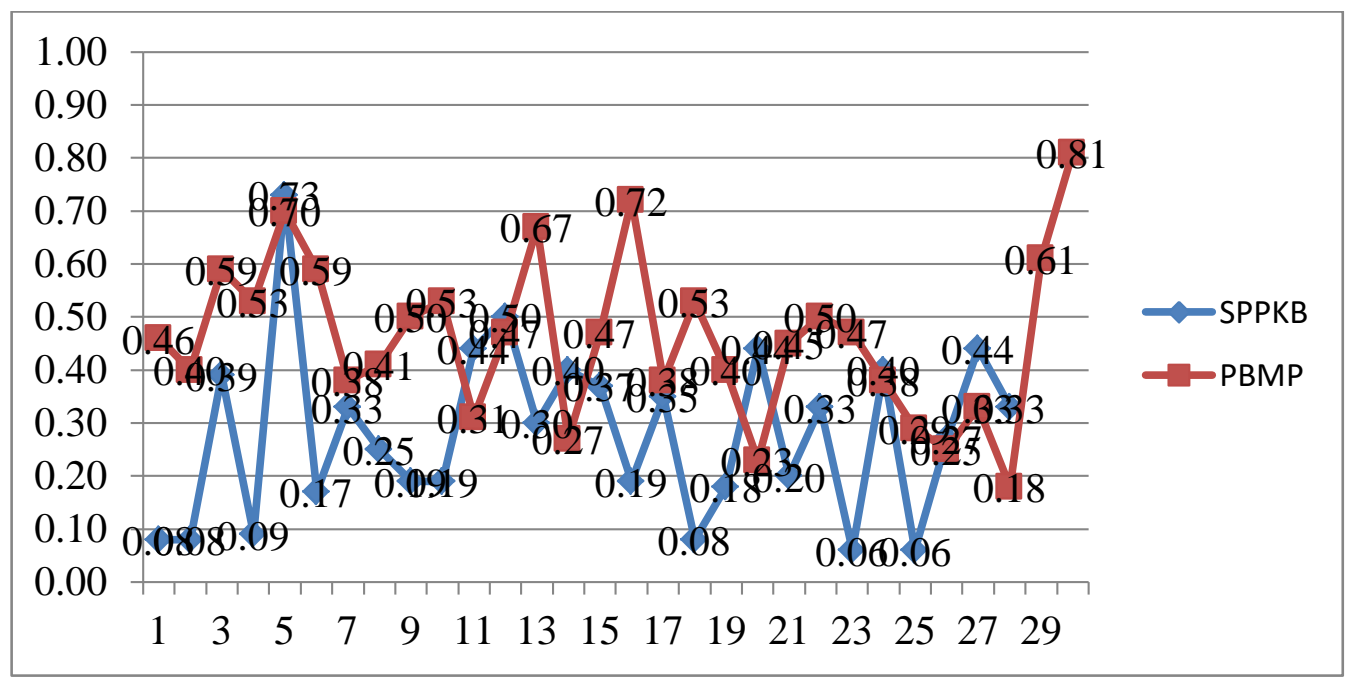

Gambar 1 : Diagram Garis N-Gain Per siswa Pada Kelas SPPKB dan PBMP 
Tabel 2 : Rekapitulasi Aktivitas Dosen Kelas SPPKB dan Kelas PBMP

\begin{tabular}{|c|c|c|c|c|}
\hline \multirow{3}{*}{ Pertemuan } & \multicolumn{4}{|c|}{ Rerata Persentase (\%) } \\
\cline { 2 - 5 } & \multicolumn{2}{|c|}{ SPPKB } & Ya & Tidak \\
\cline { 2 - 5 } & Ya & Tidak & 100 & - \\
\hline I & 100 & - & 100 & - \\
\hline II & 100 & - & & \\
\hline
\end{tabular}

Berdasarkan Tabel 2 diketahui bahwa rerata persentase aktivitas dosen kelas SPPKB pertemuan I adalah $100 \%$ dan aktivitas dosen kelas PBMP pertemuan I adalah 100\%. Pada kelas PBMP rerata persentase aktivitas dosen kelas SPPKB pertemuan II adalah $100 \%$ dan aktivitas dosen kelas PBMP pertemuan II adalah 100\%. Artinya secara umum aktivitas dosen kelas SPPKB dan kelas PBMP telah dilaksanakan secara maksimal. Aktivitas mahasiswa pada kelas SPPKB dan kelas PBMP dapat dilihat pada Tabel 3 berikut :

Tabel 3 : Rekapitulasi Aktivitas Mahasiswa Kelas SPPKB

\begin{tabular}{|c|c|c|c|c|c|c|c|c|}
\hline Pertemuan & \multicolumn{7}{|c|}{ Aktivitas (\%) } & $\begin{array}{c}\text { Rerata } \\
\text { Persentase } \\
\end{array}$ \\
\cline { 2 - 9 } & 1 & 2 & 3 & 4 & 5 & 6 & 7 & \\
\hline I & $75,00 \%$ & $64,29 \%$ & $71,43 \%$ & $67,86 \%$ & $82,14 \%$ & $71,43 \%$ & $78,57 \%$ & $72,95 \%$ \\
\hline II & $78,57 \%$ & $67,86 \%$ & $71,43 \%$ & $78,57 \%$ & $85,71 \%$ & $75,00 \%$ & $71,43 \%$ & $75,51 \%$ \\
\hline Rerata & \multicolumn{10}{|c|}{} & $74,23 \%$ \\
\hline
\end{tabular}

Berdasarkan Tabel 3 terlihat bahwa rerata persentase aktivitas mahasiswa kelas SPPKB pertemuan I sebesar $72.95 \%$, sedangkan pada pertemuan II rerata persentasenya meningkat sebesar $75,51 \%$.
Hal ini menunjukkan sudah terjadi peningkatan namun pembelajaran belum terjadi secara maksimal. Sebaliknya dengan aktivitas mahasiswa kelas PBMP yang dapat dilihat pada Tabel 4 berikut:

Tabel 4 : Rekapitulasi Aktivitas Mahasiswa Kelas PBMP

\begin{tabular}{|c|c|c|c|c|c|c|c|}
\hline \multirow[t]{2}{*}{ Pertemuan } & \multicolumn{6}{|c|}{ Aktivitas (\%) } & \multirow{2}{*}{$\begin{array}{c}\text { Rerata } \\
\text { Persentase } \\
(\%)\end{array}$} \\
\hline & 1 & 2 & 3 & 4 & 5 & 6 & \\
\hline II & $80,00 \%$ & $90,00 \%$ & $86,67 \%$ & $83,33 \%$ & $86,67 \%$ & $86,67 \%$ & $85,56 \%$ \\
\hline II & $90,00 \%$ & $90,00 \%$ & $90,00 \%$ & $93,33 \%$ & $93,33 \%$ & $86,67 \%$ & $90,56 \%$ \\
\hline Rerata & & & & & & & 88,06 \\
\hline
\end{tabular}


Berdasarkan hasil pengamatan Tabel 2 terlihat bahwa rerata persentase pertemuan I kelas PBMP adalah 85,56\%, sedangkan pada pertemuan II rerata persentase pertemuan II kelas PBMP

\section{KESIMPULAN}

Berdasarkan hasil penelitian dan analisis data yang telah dilakukan dapat disimpulkan bahwa terdapat perbedaan hasil belajar mahasiswa mata kuliah bioteknologi pada kelas Strategi Peningkatan Kemampuan Berpikir (SPPKB) dan Pemberdayaan Berpikir Melalui Pertanyaan (PBMP). Dari hasil belajar dapat dilihat hasil N-Gain, pada kelas kelas SPPKB 0.28 dengan kategori rendah sedangkan PBMP yaitu 0.46 dikategorikan sedang. Dengan demikian strategi Pemberdayaan Berpikir Melalui Pertanyaan (PBMP) lebih tinggi debandingkan dengan Strategi Peningkatan Kemampuan Berpikir (SPPKB) khususnya pada materi kultur jaringan tumbuhan pada semester VI Pendidikan Biologi Universitas Lancang Kuning Pekanbaru.

\section{REFERENSI}

Abdurrahman, M. 1999. Pendidikan Bagi Anak Berkesulitan Belajar. Rineka Cipta. Jakarta.

Anisa, Joko, \& Sulifah. 2013. Efektivitas Strategi Pembelajaran Peningkatan Kemampuan Berpikir (SPPKB) mengalami peningkatan menjadi $90,56 \%$. Hal ini berarti hampir seluruh mahasiswa pada kelas PBMP terlibat dalam poses pembelajaran.

Terhadap Hasil Belajar dan Aktivitas Siswa Menggunakan Strategi Synargetic Teaching (Pada Mata Pelajaran Biologi di SMP Negeri 10 Jember). Jurnal Pancaran, 2 (4): 100-110.

Anwar, K. 2010. Perencaan Sistem Pembelajaran Kurikulum Tingkat Satuan Pendidikan (KTSP). Alfabeta. Bandung.

Arikunto, S. 2013. Prosedur Penelitian: Suatu Pendekatan Prakti. Rineka Cipta. Jakarta.

Corebima, A.D. 2009. Pengalaman Berupaya Menjadi Guru Profesional. Malang. Departemen Pendidikan Nasional Universitas Negeri Malang.

Dimyati \& Mudjiono. 2006. Belajar dan Pembelajaran. Rineka Cipta. Jakarta.

Fraenkel, J, R \& Wallen, N, E. 2009. How To Design and Evaluate Research In Education. McGraw-Hil. Singapore.

Meltzer D.E. 2002. The Relationship Between Mathematics Preparation and Conceptual Learning Gains In Physics: A Possible "Hidden Variable" In Diagnostic Pretes Scores. American Journal of Physics, 70 (12): 1259-1268.

Purwanto, M. N. 2002. Psikologi Pendidikan. Remaja Rosda Karya. Bandung. 
Sanjaya, W. 2009. Strategi Pembelajaran Berorientasi Standar Proses Pendidikan. Kencana Prenada Media. Jakarta.

Sugiyono., 2007. Statistika untuk penelitian. Alfabeta. Bandung

Sugiyono., 2009. Metode Penelitian Kuantitatif, Kualitatif dan $R \& D$. Alfabeta. Bandung.

Suwarno, W. 2009. Dasar-Dasar Ilmu Pendidikan. Ar Ruzz Media. Yogyakarta.

Suyanto \& Jihat, A. (2013). Menjadi Guru Professional Strategi Meningkatkan
Kualifikasi dan Kualitas Guru di Era Global.Elangga. Jakarta

Utami, N. (2003). Model Pembelajaran Terpadu. Bumi Aksara. Jakarta

Wulandari, A. 2012. Pengaruh Model pembelajaran Thinking Empowerment by Questioning dengan Metode Eksperimen terhadap Kemampuan Berfikir Rasional dan Hasil Belajar Biologi Siswa Kelas XI SMA Negeri 2 Tanggul Jember. Jember. Program Studi Pendidikan Biologi FKIP Universitas Jember. 